\title{
Lyt til borgerne - hvis I vil lykkes på tværs
}

\author{
Af Annemette Digmann *)
}

\begin{abstract}
Resumé
Ledelse og samarbejde på tværs af fag, afdelinger og sektorgrænser er kommet for at blive. Oftere og oftere oplever borgere, at de kommer i klemme mellem systemer, der ikke er i stand til at arbejde på tværs. For at blive klogere på vanskelighederne og hvordan de kan overkommes, har jeg fulgt adskillige 'på tværs' samarbejder gennem en årrække. Denne artikel bygger på, at jeg gennem en længere periode har fulgt Psykiatriens Hus i Aarhus, der er et tilbud, der forsøger at bygge bro mellem den regionale behandlingspsykiatri og socialpsykiatrien i kommunen.
\end{abstract}

Artiklen begynder med en beskrivelse af den aktionslæring, der foregik i samarbejde med ledelsen i 2019 og slutter med den analyse som aktionsforskningen bidrog med i løbet af 2020. Artiklen beskriver hvordan ledelsen i Psykiatriens Hus forsøger at omsætte den viden, der findes om ledelse på tværs, til praktiske handlinger. En hovedkonklusion er, at det lykkes at samarbejde på tværs, når man tager udgangspunkt i borgerperspektivet.

\section{Emneord}

Psykiatri på tværs; partnerskabsledelse; borgerinddragelse, aktionslæring og -forskning, borgeransvarlighed.

*) Annemette Digmann arbejder som selvstændig aktionsforsker og er cand.mag. og Ph.d. Har en lang række ansættelser som leder i det offentlige bag sig. Fra 2006 til 2016 som innovationschef i Region Midtjylland. Har siden 2000 arbejdet som forsker primært med fokus på ledelse. 


\section{A. Introduktion}

\section{Baggrund}

I løbet af det seneste årti har jeg forsket i ledelse og samarbejde på tværs. Jeg blev interesseret i emnet, fordi jeg selv som Innovationschef i Region Midtjylland oplevede, hvor svært det var, når opgaven krævede, at vi skulle samarbejde på tværs af fag, afdelinger og sektorgrænser.

Det gjorde mig nysgerrig, og derfor begyndte jeg at undersøge, hvorfor samarbejde og ledelse på tværs var så vanskeligt, og om det var muligt at overvinde vanskelighederne.

I første omgang fulgte jeg fem 'tvungne' samarbejder på sundhedsområdet, idet det var og stadig er et krav, at kommunerne i en region sammen med regionen hvert fjerde år skal udarbejde en sundhedsaftale, der udgør rammen for det tværsektorielle samarbejde. To af samarbejderne fandt sted på det øverste strategiske niveau, hvor opgaven var at formulere den overordnede ramme for samarbejdet, mens de tre andre foregik, hvor det var ét hospital, der skulle etablere et samarbejde både med almen praksis og de kommuner, hvis borgere er brugere af hospitalet. I de tre sidstnævnte eksempler er opgaven stadig rammesættende, men tættere på praksis, og et sådant samarbejde igangsætter ofte konkrete projekter, der i praksis skal vise vejen for samarbejdet på tværs.

Den viden, der er kommet ud af studierne, har jeg både beskrevet i forskellige sammenhænge og videreudviklet i praksis både internt i en kommune, hvor fag og afdelinger skal samarbejde, på tværs af intuitioner på statens område og på tværs af sektorgrænser.

Sidst på året 2018 fik jeg en forespørgsel fra et af de tværsektorielle samarbejder på psykiatriområdet om at bidrage med min viden om, hvordan man kan lykkes med at lede på tværs. Samarbejdet kom til at vare i $1 \frac{1}{2}$ år og da det er første gang, jeg har haft mulighed for at arbejde som aktionsforsker sammen med en ledergruppe, der i praksis og til daglig skal lede på tværs for at kunne løse opgaven for borgerne, vil jeg i denne artikel bidrage med de erfaringer, der er fremkommet, og som supplerer den eksisterende viden, idet der er forskel på at rammesætte det tværsektorielle samarbejde og udføre det til dagligt.

Dette casestudie er en del af et større forskningsprojekt, hvor fokus har været tværgående ledelse og samarbejde. De første par år koncentrerede jeg mig om, den ledelse, der skulle krydse sektorgrænser. Senere inddrog jeg cases internt i organisationer og fra 2016 udvidede jeg fokus, således at 'på tværs' siden også har dækket over inddragelse af borgere. Samskabelse har i flere år været et slogan i mange offentlige virksomheder og jeg har derfor undersøgt, hvordan man lykkes med at inddrage borgere i samarbejdet, samtidig med at man også skal arbejde på tværs af fag, afdelinger og sektorer. 


\section{Problemstillingen}

Artiklens problemstilling er at undersøge, hvilke vanskeligheder der opstår, når ledere i daglig praksis både skal varetage den fælles institutions interesser og samtidig tage hensyn til den organisation, de kommer fra. Jeg vil gerne bidrage med viden om, hvad det er værd at være opmærksom på, når man skal have det tværgående samarbejde til at fungere i dagligdagen, og om der er barrierer, der gør det vanskeligt at benytte den eksisterende viden.

\section{Hvad er udfordringerne for Psykiatriens Hus?}

I løbet af de seneste år er der etableret Psykiatri Huse i flere kommuner og regioner, således også i det Østjyske.

I 2018 vedtog politikerne i Aarhus Kommune og Region Midtjylland at etablere et Psykiatriens Hus, med det formål at sætte borgernes recovery-proces i centrum.

Visionen var, at Psykiatriens Hus i særlig grad skulle fokusere på opgaver, hvor den kommunale socialpsykiatri, almen praksis og den regionale behandlingspsykiatri er nødt til at arbejde på tværs for at tilbyde borgerne en helhedsorienteret indsats.

Psykiatrien ligger med sit naturvidenskabelige fokus på evidens, standardisering og medicinsk behandling holdningsmæssigt et stykke fra den socialpædagogiske tilgang, der med holistiske metoder har fokus på relationer, samspil og kommunikation. I mange år har den psykiatriske fagtilgang til borgerne trumfet den socialpædagogiske recovery-strategi. Psykiatriens Hus har bl.a. til formål at bygge bro mellem de modsatrettede tilgange til borgernes helbredelse.

En afdelingsledelse (bestående af en ledende overlæge og oversygeplejerske fra regionspsykiatrien) og en centerchef fra kommunen fik til opgave at realisere visionen. Første skridt var at få ansat den daglige ledelse af Psykiatriens Hus.

Lederne blev ansat i sensommeren 2018, og Psykiatriens Hus åbnede for borgerne 1.februar 2019. Den ene leder var socialrådgiver og kom fra Aarhus Kommune; den anden havde en baggrund som sygeplejerske og havde senest været ansat i Psykiatrien i Region Midtjylland. Begge havde ledererfaringer fra det hierarkiske ledelsessystem. I efteråret 2020 var der omkring 70 medarbejdere ansat i Psykiatriens Hus, og de tilknyttede borgere har enten en kommunal eller regional kontrakt, der gør det muligt at få gavn af de mange tilbud, hvad enten der er tale om en midlertidig overnatningsplads eller deltagelse i et rådgivningsforløb.

Har du som læser lyst til at vide mere om Psykiatriens Hus, kan du finde mere viden på psykiatrienshus.aarhus.dk 


\section{Oversigt over artiklen}

Artiklen er bygget op omkring det aktionslæringsforløb, jeg har gennemført i samarbejde med Psykiatriens Hus. Først beskriver jeg i afsnit B om forskningsdesign forløbet fra aktionslæring til aktionsforskning. Analysen af interview og observationer er samlet i afsnit C, som jeg kalder loering fra Psykiatrien Hus, da analysen er koncentreret om, hvad ledelsen lokalt og alle andre kan lære af de indhentede erfaringer. Derfor har overskrifterne i afsnit $\mathrm{C}$ et normativt præg, således at konklusionen af analysen er formuleret i overskriften.

Hvis ikke samarbejdet på tværs kan mærkes af borgerne, har alle parter i det tværgående samarbejde et problem. Derfor har jeg interviewet en lille gruppe af de borgere, der benytter tilbuddene $\mathrm{i}$ Psykiatriens Hus. Borgernes udsagn er analyseret og beskrives i afsnit D.

I afsnit E opsamler jeg erfaringerne fra Psykiatriens Hus og undersøger om der er produceret ny viden om ledelse og samarbejde på tværs.

Konklusion, anbefalinger og perspektivering findes i afsnit F.

\section{B. Forskningsdesign}

\section{Et generisk på Tværs forløb}

Jeg har erfaring for, at udgangspunktet for et aktionslærings forløb er, at parterne bruger en times tid på at (re)formulere visionen. Det er vigtigt at sikre sig, at parterne har samme forståelse af den politiske vision; at de får den konkretiseret og får nedbrudt visionen i overkommelige bidder, så det er muligt at forestille sig, hvilke delmål der skal være realiseret indenfor en given tidsperiode.

Når visionen er tydelig og accepteret af parterne, er næste skridt at få opstillet de spilleregler, der skal bidrage til, at parterne kan løse opgaven. I et partnerskab er der andre spilleregler end dem, ledere og medarbejdere kender fra det hierarkiske system. De spilleregler, der skal gælde i et partnerskab, findes ved at parterne beskriver hvilke organisatoriske og personlige barrierer, der kan forhindre samarbejdet på tværs. Når spillereglerne er formuleret, opfordrer jeg til, at dét team, dén afdeling eller det tværsektorielle partnerskab, der skal samarbejde, går i gang med arbejdet, samtidig med at de evaluerer deres handlinger.

Ideen er, at det er lettere at handle sig til ny viden end at tænke/læse sig frem til, hvad der vil virke.

Den enkleste metode er at optage eksempelvis møder på telefonen og sende optagelsen til en udenforstående. Det er vigtigt, at den, der skal lytte med, er uafhængig og har mulighed for at give reelle tilbagemeldinger uden at stikke noget under stolen. 
Den, der lytter med, skal være opmærksom på, hvordan målene bliver til handlinger, og om spillereglerne bidrager positivt til samarbejdet, eller om der skal formuleres nye.

Det var den proces, jeg forestillede mig kunne være gavnligt for at få gang i samarbejdet på tværs i Psykiatriens Hus.

\section{Aktionslæring i Psykiatriens Hus}

I efteråret 2018 aftalte jeg med ledelsen at påbegynde et aktionslæringsforløb, der i første omgang skulle gennemføres i kalenderåret 2019 og som senere blev udvidet med yderligere et halvt år.

Forløbet bestod i, at jeg mødtes med leder- og chefgruppen tre gange. Gruppen bestod af to regionale og en kommunal chef, to sekretariatsmedarbejdere fra henholdsvis region og kommune og de to ledere, der udgjorde den daglige ledelse i Psykiatriens Hus. I perioden mellem møderne fik jeg tilsendt optagelser af de fælles ledermøder, der blev afholdt cirka en gang om måneden. Disse optagelser gav mig viden om gruppens vanskelighederne ved at arbejde på tværs og gav mig mulighed for at komme med ideer til, hvordan vanskelighederne kunne overvindes.

Herudover har jeg mødtes seks gange med de to medlemmer af den daglige ledelse i løbet af 2019.

I første fase arbejdede den store ledelsesgruppe med at formulere en konkretisering af den politisk vedtagne vision for Psykiatriens Hus. På et møde i februar 2019 blev følgende vision formuleret:

"At der i løbet af 2019 etableres et så stærkt 'vi-hus' som muligt. Visionen for 2019 er lykkedes, hvis:

- borgernes behov trumfer fag-faglighed og/eller administrative procedurer

- virkeligheden trumfer det oprindelige notat om Borgernes Psykiatrihus

- medarbejderne oplever, at de kan gøre dét, der giver mening for borgerne

- medarbejderne kontinuerligt bliver bedre til at tage (og handle på) borgerperspektivet

- ingen har behov for at markere, hvor man kommer fra (organisatorisk)

- at ledelsen (både de to og de fem) agerer som et VI

- at de pårørende og de frivillige oplever, at de indgår både som aktive medspillere og som medudviklere af nye tilbud.

Samtidig formulerede gruppen de spilleregler, der skulle bidrage til at lykkes med samarbejdet på tværs. Spilleregler blev eksempelvis formuleret således:

- "At dagsordenen til ledermøder indeholder strategipunkter som: vision, læring, strategi

- Læring undervejs - hvis der opstår behov for at forstå, hvad der sker i relationerne 
- Stil spørgsmål og vær nysgerrig."

Den første spilleregel fremkom ved, at jeg havde lyttet mig til, at indholdet på ledermøderne primært drejede sig om den daglige drift, og at de mere langsigtede, strategiske emner ofte blev skubbet til det efterfølgende møde. Her skete det samme, da der i mellemtiden var opstået nye driftsmæssige problemstillinger, som lederne valgte at prioritere tiden til.

Spillereglen skulle bidrage til, at dagsordenen hver gang gav plads til et strategisk emne, som eksempelvis hvordan man kan inddrage borgere og pårørende, at der var lavet et oplæg og afsat tid til drøftelserne. Lige gyldig hvilke driftsmæssige forstyrrelser, der var opstået, skulle ledergruppen forsøge at holde et strategisk fokus, inden de lod sig opsluge af driften.

En anden spilleregel havde til formål at fastholde deltagernes nysgerrighed på hinandens vilkår og erfaringer, ved at man stillede hinanden spørgsmål.

Jeg brugte bl.a. optagelserne fra ledermøderne til at undersøge, om spillereglerne blev fulgt, om nogle skulle droppes, eller om der skulle formuleres nye.

I en tilbagemelding til den store ledelsesgruppe i maj kunne jeg som eksempel beskrive, at de stadig var meget hurtige til at komme med egne løsninger. De glemte at stille spørgsmål og være nysgerrige på hinandens perspektiver.

En ny spilleregel kunne derfor være, at en deltager blev udnævnt til at være ansvarlig for, at aftalerne blev overholdt. Når først et problem er blevet påpeget i plenum, kan det være vanskeligt at fortsætte med de indgroede vaner.

I forhold til den daglige ledelse kunne jeg ligeledes lytte mig til, hvilke vanskeligheder de stod midt i. Når de ikke selv henvendte sig, valgte jeg at skrive til dem: 'er I interesserede i et møde om ....'. De seks møder jeg havde med den daglige ledelse i 2019 er kommet i stand på baggrund af de problemstillinger, jeg lyttede mig til, at det var værd at bruge tid på, for at lykkes som tværgående ledelse.

\section{Fra aktionslæring til aktionsforskning}

I forsommeren 2020 vedtog den store ledelsesgruppe at sige ja til et forslag om at opsamle den viden, der på det tidspunkt var opnået om det tværsektorielle samarbejde. 
Det betød samtidig, at jeg påtog mig rollen som forsker med følgende fokus: hvilken brugbar læring er i perioden 2019-20 fremkommet om daglig ledelse af et tværsektorielt tiltag? Der skal være tale om viden, der kan formidles til andre, der skal indgå i praktiske ledelsespartnerskaber på tværs.

I juni interviewede jeg seks repræsentanter fra den store ledergrupper, og i august blev yderligere otte medarbejdere og seks borgere interviewet.

Denne artikel bygger således på analyse af interview, observationer og interaktioner med ledelsesniveauerne i Psykiatriens Hus. I analysen har jeg - inspireret af Peter Dahler-Larsen - valgt at fokusere på udsagn, som repræsenterer flertallets opfattelser, således at enkeltstående udsagn, der, selv om det repræsenterer et spændende synspunkt, ikke er medtaget.

Analysen blev fremlagt for den store ledergruppe i august 2020 og vil blive diskuteret med medarbejderne i december.

På baggrund af analysen af ledernes handlinger vil jeg i denne artikel argumentere for:

- Hvorfor forberedelsestid er nødvendig

- Hvorfor det er vigtigt at sikre sig støtte undervejs

- Hvorfor det er nødvendigt at forhandle grænserne for sit ledelsesrum

- Hvorfor borgerperspektivet er det fælles tredje, der kan mindske egeninteressen

\section{Ledelse på tværs - læring fra Psykiatriens Hus}

\section{Find de fælles løsninger}

Det er en særlig udfordring at lede på tværs af fag, afdelinger og sektorer. Det er der mange grunde til, men da borgernes behov sjældent passer til de fag- og sektorgrænser, der er etableret i den offentlige sektor, er vi nødt til at overkomme vanskelighederne, hvis vi skal bidrage til at løse de problemer, som borgerne har.

Alle involverede ledere og medarbejdere opfattede Psykiatriens Hus som en chance for at tage udgangspunkt i borgernes behov, så de forskellige faglige kompetencer og sektorer ville begynde at samarbejde bedre om at give borgerne de tilbud, de har behov for.

Helt fra begyndelsen var der meget gejst til stede og en oplevelse af medvind, samtidig med at lederne også var bekymrede for, om de ville lykkes med at få skabt en ny fælles kultur, når to store 
organisationer, der er kendetegnet ved både at have hver deres selvbevidste kultur og forskellige rammevilkår, som de eksempelvis opleves i lovgivning, IT-systemer, retningslinjer og så videre.

Der var fra start en erkendelse af, at man som leder skal kunne mestre et dobbeltperspektiv, idet man dels skal være en del af et fællesskab i Psykiatriens Hus, og dels at man skal være en aktiv del af hvert sit bagland. Det betyder, at man ikke som sædvanligt kan læne sig op af sit bagland, når der opstår problemer. I stedet skal man hver gang finde en fælles løsning, som alle parter er tilfredse med.

Som eksempel på en fælles løsning kan jeg nævne, at en borger, der er tilknyttet Psykiatriens Hus, via kommunen kan have en overnatningsplads i 24 timer, mens en tilsvarende borger fra regionens psykiatritilbud kan benytte pladsen i 5 døgn. Det er en forskel, som det er vanskeligt for medarbejderne at forklare borgerne. Medarbejderne håndterer i de fleste tilfælde reglerne lempeligt. En borger, der havde en kommunal kontrakt, opfatter det således: "Der skal være plads til, at man kan få overnatning nr. to uden at skulle argumentere. Nu kan jeg få et døgn ad gangen. Ligegyldigt om man er kommunalt eller regionalt tilknyttet Psykiatriens Hus, så gør medarbejderne meget for at hjælpe på tværs. Jeg har fået en blandingsordning - og det er så godt. Sidst fik jeg fire overnatninger for at undgå indlæggelse. Næsten alt kan lade sig gøre, hvis det gir mening.”

Ledelsen i Psykiatriens Hus er nødt til enten at finde én løsning, der gælder for alle borgere, ligegyldigt hvilken organisation man oprindeligt er tilknyttet, eller stå på mål for, at medarbejderne gør det, der gir mening for borgerne, selv om det er på kant med reglerne.

\section{Forskellene skal overkommes}

De to ledere blev ansat af en tværsektoriel chefgruppe med repræsentanter fra region og kommune, og det var vigtigt for ansættelsesudvalget, at de to ledere ikke bare kom fra hver sin organisation, men også at de var forskellige i deres tilgang til ledelse. Den ene blev valgt, fordi hun var en 'handlingskvinde', den anden, fordi hun var rigtig god til processer.

Det var dog ikke den eneste forskel. Både de regionale chefer og den kommende regionale leder var på forskellig vis inddraget $\mathrm{i}$ det forberedende arbejde, hvorimod både den kommunale chef $\mathrm{og}$ kommende leder først kom ind i arbejdet på et senere tidspunkt, idet de først blev ansat, da beslutningen om etableringen af Psykiatriens Hus var vedtaget.

En tredje forskel bestod i, at den regionale leder skulle referere til den samme chefgruppe som tidligere, mens den kommunale leder fik en ny chef, og det betød, at de havde behov for mere tid til at opbygge deres relation. 
Mens kommunen skulle udvikle nogle helt nye indsatser fra bunden, så skulle regionen forandre en hospitalsafdeling med indlæggelser til en mere fleksibel døgnfunktion væk fra hospitalet, samtidig med, at der skulle udvikles nye tilbud.

Forskellene og kompleksiteten betød, at det tog tid at komme på omgangshøjde med hinanden. Når det er tilfældet, skal der afsættes god tid til det forberedende arbejde.

Når man igangsætter et samarbejde på tværs, så er der tale om en investering både af tid og andre former for ressourcer. Der skal afsættes tilstrækkelig tid til, at lederne finder hinanden og får sig talt sig ind på, hvilke værdier der skal kendetegne den nye fælles kultur, og hvordan værdierne skal kunne mærkes i dagligdagen. I sådan et arbejde kan der opstå uenigheder, da parterne befinder sig i et konfliktfyldt farvand, hvor de både skal opbygge et nyt tværgående tilbud og være loyale overfor de organisationer, de repræsenterer.

Opstår der uenigheder, der ikke kan løses på ledernes niveau, skal cheferne være klar til at træde til. Den nødvendige tid skal derfor også reserveres på chefniveau. Det kan være en udfordring i sig selv, da også chefniveauet har travlt og måske har tendens til først at træde til, når det er gået galt.

\section{Forberedelsestid og støtte er nødvendig}

Lederne havde fire måneder til det forberedende arbejde, men tiden blev primært brugt til at få de mange praktiske opgaver i Psykiatriens Hus på plads. Det drejede sig både om at ansætte de mange medarbejdere, at få huset til at fungere og løse mangeartede praktiske opgaver. Tiden blev i langt mindre grad brugt til de mere strategiske ledelsesopgaver, der kunne have bidraget til at få overblik over de mange, mange opgaver, og dels have foretaget en prioritering, dels have uddelegeret flere opgaver til de medarbejdere, der stod og trippede for at komme i gang.

Allerede fra start viste der sig et stort behov for, at lederne blev understøttet med administrative kompetencer. Det skete først efter næsten $1 \frac{1}{2}$ år. Det er nyttigt på forhånd at overveje, hvilke administrative ressourcer et hus med 70 medarbejdere og flere hundrede tilknyttede borgere har behov for, så ledelsen kan koncentrere sig om at udøve ledelse.

I begyndelsen af samarbejdet i ledelsen blev der tilknyttet en supervisor til de to daglige ledere, og kort efter indvielsen blev jeg som nævnt tidligere tilknyttet hele ledergruppen (inklusive chefer og sekretariat) som aktionsforsker.

Det er vigtigt at pointere, at de, der i det daglige skal udøve ledelse på tværs, får supervision både fra start og undervejs. Erfaringerne fra Psykiatriens Hus peger på, at det ikke skal være et tilbud, men et krav, da det ikke er en enkel sag at overvinde de vanskeligheder, der opstår, når man skal 
arbejde på tværs. Skal lederne selv sørge for at få supervision, er der en risiko for, at det er en af de opgaver, der bliver udskudt, fordi der er så mange andre, mere konkrete opgaver, der står i kø. Mange ledere har vanskeligt ved at bede om hjælp. De ønsker at klare sig selv, og det kan opfattes som utilstrækkelighed, hvis man har behov for støtte. Når man står midt i en kompleks opgave, der er fyldt med dilemmaer og paradokser, og når dét at lede på tværs er en ny opgave, så er støtte nødvendig. Nøjsomhed er ikke vejen frem. Både ledere og chefer er socialiseret i det hierarkiske ledelsessystem, og nu er kravet, at de skal indgå i et ligeværdigt partnerskab på tværs. Det kræver nye kompetencer og nye spilleregler. At finde frem til, hvad der vil fungere i Psykiatriens Hus, kræver ressourcer, og der skal afsættes tid til, at chefgruppen har mulighed for regelmæssigt at tage kontakt til de nyansatte ledere - bare for at høre, hvordan det går, uden at der behøver at være åbenbare problemer, der skal adresseres.

Set i bagklogskabens klare lys havde det været vigtigt at arbejde bevidst med både at opnå en balance i ledelsen i forhold til opgavemængde og vidensgrundlag og få viden om og træning i, hvordan man leder på tværs. Jeg argumenterer ikke for, at man skal gennemføre et Master-modul i ledelse på tværs, inden man går i gang. Mindre kan gøre det, og et første skridt kan være at svare på spørgsmålet: 'hvad er det mindste, vi kan nøjes med at vide, inden vi kaster os ud i forberedelsesfasen?'. Den opnåede grundviden skal suppleres med den løbende læring, der sker undervejs. Denne erfarede viden om at fungere som del af et ligeværdigt partnerskab er utrolig vigtig som supplement til den viden, lederne har med fra det hierarkiske ledelsessystem.

\section{Få tydeliggjort dit/jeres ledelsesrum}

En del af det forberedende arbejde er at få afklaret sit ledelsesrum. Det kræver en kontinuerlig dialog mellem de ansættende chefer og de nyansatte ledere. Et ledelsesrum er betegnelsen for det råderum, ledere har på de forskellige niveauer i en organisation. Det er beskrevet i mange sammenhænge, men det skal nyfortolkes i en tværsektoriel sammenhæng. Der er i et tværsektorielt set-up i særlig grad behov for at få afstemt de forventninger, parterne har til hinanden og få udarbejdet spilleregler for, hvordan samarbejdet skal udspille sig, og hvordan parterne kan både udfordre og udforske ledelsesrummet, samtidig med at ledelsesrummet balanceres med medarbejdernes handlerum.

Når man leder på tværs, kan det ikke undgås, at man kommer til at gå ind i hinandens ledelsesrum. Det er noget, de fleste ledere afholder sig fra og oplever som ubekvemt, hvis det alligevel sker. Nogle spilleregler kan opstilles på forhånd, mens andre skal formuleres, efterhånden som parterne bliver klogere. Hvordan man med ro i sindet kan gå ind i kollegaens ledelsesrum, hører til i den sidste kategori, mens det at aftale, hvordan beslutninger tages, og konflikter opløses, ofte kan klares på forhånd. 
Forberedelsestid er nødvendigt, når noget nyt skal påbegyndes, men lige så nødvendigt er det på forhånd at afsætte tid til, at det er muligt at blive klogere undervejs. Mange af de foreløbige ideer og tiltag kan sagtens have behov for en justering.

\section{Sæt borgerperspektivet i centrum for at overvinde forhindringerne}

Når man skal løse opgaver på tværs af fag- og sektorgrænser, så drejer det sig om at neddrosle egeninteressen til fordel for det fælles perspektiv - og det, der er fælles, er borgernes ønsker og behov. Der er altid mange udfordringer, når man skal arbejde på tværs, og de overvindes ved at sætte borgeren i centrum. I stedet for at fortælle, hvad henholdsvis behandlingspsykiatri og socialpsykiatri kan levere, så giver det meget mere mening at tage udgangspunkt i, hvad borgeren har brug for.

Når man etablerer et Psykiatriens Hus, så bliver der behov for at udvikle en ny fælles kultur. Både kommunen og regionen har regler og retningslinjer, der giver mening i hver enkelt organisation, men som måske enten ikke er relevante i den ny enhed eller vil spænde ben for den fælles opgaveløsning

Jeg nævnte tidligere eksemplet med de forskellige regler, der var for brugen af overnatningspladser. Herudover kan det være forskelligt om medarbejderne skal bære navneskilte og have alarm, eller hvilke regler, der er for brug af en kaffemaskine.

Det er næsten ligegyldigt, hvilket emne der er tale om, så har behandlingspsykiatrien og socialpsykiatrien hver deres måde at agere på. Parterne kan bruge lang til på at diskutere, om det er den ene organisations regelsæt eller den andens, der skal gælde. Erfaringerne fra Psykiatriens Hus viser tydeligt, at når man tager borgernes perspektiv, så behøver man ikke at bruge tid på de mange diskussioner - til gengæld kan dét at fokusere på, hvad borgerne har behov for, være med til at skabe den nye fælles kultur. Hvis vi tager eksemplet med, om man skal bruge navneskilte, så går regionale medarbejdere med skilt, når de arbejder på Psykiatrisk Hospital, mens det ikke gælder for de kommunalt ansatte i socialpsykiatrien.

Hvad skal medarbejderne gøre i Psykiatriens Hus? Det er en ledelsesopgave at hjælpe medarbejderne på vej, og her kan det give mening at tage udgangspunkt i, hvad borgerne efterspørger. Det kan sagtens være, at ingen af parterne ved, hvad borgerne ønsker. Så må man spørge dem - og de er jo til stede i huset, så det er ikke det store arbejde at interviewe nogle stykker. Når interviewene tegner et billede, man kan handle på, så kan det være en idé at gennemføre en prøvehandling. Det kan være, at ingen af de adspurgte borgere oplever, at de har behov for at medarbejderne bærer navneskilt. For at teste om det er rigtigt, kan man aftale, at ingen bærer 
navneskilt i fx 4 uger. Herefter evaluerer man og vurderer, om man har tilstrækkelig viden til at fastsætte en regel, der skal gælde for Psykiatriens Hus.

\section{Der skal overvindes barrierer, hvis borgerperspektivet skal vise vejen}

Hver gang parterne lader borgerperspektivet definere en ny regel, bidrager det til, at en ny fælles kultur opstår. Ledelsesopgaven er at sætte rammen for, at medarbejderne sammen med borgerne kan handle sig frem til den nye kultur - fremfor at diskutere, hvilke regler der skal gælde.

Det lyder måske enkelt, men når alle er opdraget til at tage sit eget fags og sin egen organisations perspektiv, så kan det opleves som udfordrende at tage udgangspunkt i et tredje perspektiv, der går på tværs af det traditionelt faglige og organisatoriske rationale. Det betyder, at borgerperspektivet ofte kan provokere hjemme-organisationen. Det er en strategisk ledelsesopgave på forhånd at drøfte, hvordan man vil møde kritik og modstand.

Da corona pandemien ramte i foråret 2020, viste forskellen på de kommunale og regionale retningslinjer sig tydeligt, og både ledere og medarbejdere giver udtryk for, at samarbejdet meget hurtigt bevægede sig fra en 'vi-holdning' til en 'os og dem' kultur.

Hovedparten af de kommunale medarbejdere blev sendt hjem, mens regionens medarbejdere fortsatte arbejdet med restriktioner. Senere blev de brugere, der kom fra behandlingspsykiatrien, testet, hvorimod de brugere, der var tilknyttet de kommunale tilbud ikke blev testet. Det betød, at halvdelen af de borgere, der benyttede køkkenet, var testet og den anden halvdel ikke. Forskellighederne frustrerede både brugere, medarbejdere og ledere.

Men når retningslinjer er meldt ud af KL, så er det ikke lige til at se bort fra dem for at formulere de retningslinjer, der skal kendetegne Psykiatriens Hus og give mening og sikkerhed for både borgere og ansatte.

Der er herudover adskillige andre benspænd, der skal overvindes, hvis det tværsektorielle samarbejde skal give den ønskede effekt. Det drejer sig om forskellig lovgivning, forskellige dokumentationskrav og retningslinjer, som det ligger uden for medarbejdernes og ledernes mulighed for at ændre.

Der er et politisk ønske om, at parterne på sundhedsområdet bliver bedre til at samarbejde. Samtidig er det de samme politikere, der laver de love og regler, der gør samarbejdet enten vanskeligt eller umuligt. 
Hvis ikke de medarbejdere, der skal tage udgangspunkt i borger-perspektivet, skal tvinges til at løse umulighederne under radaren, er der behov for, at topledelserne påtager sig at gøre politikerne opmærksomme på, at de eksisterende lovgivninger skal tilpasses de politiske visioner.

På den anden side kan det også være mentale forhindringer hos medarbejderne, der forhindrer samarbejdet med borgerne. En medarbejder fortæller, at hun har oplevet stor fleksibilitet i bestræbelsen på at følge menneskers behov på tværs af sektorgrænserne. Når hun er i tvivl, spørger hun ledelsen om hun er på rette vej: "Der er endnu ingen, der har sagt nej. Jeg gør dét, der er vigtigt for det enkelte menneske. Det er godt for borgeren og for min arbejdsglæde. Jeg skal måske prøve noget mere vildt, for jeg får sjældent nej.”

De mentale barrierer kan ofte vise sig at være større end de reelle. Det kræver tydelig ledelsesopbakning, hvis medarbejderne skal bevæge sig ud af komfortzonen og afprøve løsninger, hvad enten de ligger inden eller uden for rammen.

\section{Hvilken forskel gør Psykiatriens Hus for borgerne?}

Både medarbejdere og borgere oplever, at Psykiatriens Hus har været en gevinst.

Medarbejderne giver udtryk for, at de kan give borgerne et langt bedre tilbud ved at være i samme hus, end de kunne tidligere. Det viser sig på to måder.

For det første får man dagligt udvidet sin horisont ved at arbejde sammen på tværs. En tidligere hospitalsansat udtrykker det på denne måde:

"Det er først dæmret for mig (sådan rigtigt), at patienterne har et liv uden for sygehuset. Tidligere har jeg kun set patienten på sygehuset og har haft svært ved at forestille mig, at de også er en del af en civil verden og har et hav af problemer dér. Det kan man på en eller anden mærkværdig måde formå at lukke øjnene lidt for, når man er på sygehuset. Den daglige omgang med socialfaglige kolleger; dét at være flyttet ud af, og at vi tager på hjemmebesøg, har ændret mit syn.”

Selvfølgelig ved denne psykiatriske sygeplejerske godt, at de indlagte borgere har et liv uden for hospitalet, men at opleve, at borgerne også er i stand til at tage bussen, bo i egen lejlighed og have relationer til familie og venner, gør en konkret forskel. Hun fortæller, at den daglige omgang med socialfaglige kolleger, dét at være flyttet ud af hospitalet og kunne tage på hjemmebesøg for alvor har ændret hendes syn på borgernes muligheder. 
På samme måde fortæller en pædagog, at hun på en aftenvagt har fået 'uvurderlig hjælp' af en sygeplejerske.

For det andet er det blevet lettere at få samarbejdet på tværs til at glide. Hvor en kommunal medarbejder tidligere kunne ringe til en kollega på hospitalet og skulle vente et par timer eller dage på, at hendes samarbejdspartner var til at få fat i, så kan de få løst grænse problemer stort set med det samme. Medarbejderne sidder på fælles kontorer, og det betyder, at der er et vidensflow på tværs og ligeledes på trods af de skodder, der er mellem de kommunale og regionale systemer. Det betyder, at medarbejderne har fået mulighed for en anderledes sparring og straks kan handle sammen med borgerne.

De borgere, der benytter tilbuddene i Psykiatriens Hus, er meget positive overfor den kultur, de møder i huset. Det kan ikke udelukkes, at de meget positive beskrivelser skyldes, at alle interviewede ikke har de bedste erfaringer med behandlingspsykiatrien. De negative oplevelser kan naturligvis også hænge sammen med, at indlagte borgere er meget syge.

Borgerne angiver samstemmende, at Psykiatriens Hus arbejder forebyggende, så man ikke ender med at blive indlagt på hospitalet. Bliver man endelig indlagt, er forløbet af kortere varighed end tidligere.

Herudover oplever borgerne, at de lærer at klare sig i livet og at kunne håndtere deres sygdom.

Hvad betinger forskellen? Alle interviewede fortæller, at de i Psykiatriens Hus bliver mødt som et menneske og ikke som en diagnose. I Psykiatriens Hus har borgerne én kontaktperson, og medarbejderne møder én i øjenhøjde. De ansatte er nysgerrige, lytter og viser omsorg. I Psykiatriens Hus oplever borgerne den tryghed, der gør, at de vover at udfordre sig selv, hvad enten det drejer sig om praktiske opgaver eller relationen til andre mennesker. Vi hører udsagn som:

"Tidligere var diagnosen min identitet. I Psykiatriens Hus har jeg skullet skabe mig en identitet som menneske."

"Pludselig var der nogen, der interesserede sig oprigtigt for mig og ikke kun for min sygdom og symptomer."

"I Psykiatriens Hus virkede det, som om de gik op i mig. Jeg var ikke bare et nummer i systemet."

I Psykiatriens Hus oplever borgerne, at de ikke får lov til at falde ned mellem de mange stole, der er i sundhedsvæsnet. Når der opstår problemer i mellemrummene, så løser medarbejderne det til 
borgernes fordel. Alle interviewede borgere giver udtryk for, at kontakten med Psykiatriens Hus i høj grad har bidraget til deres helbredelse.

Det er en både udfordrende og nødvendig opgave for ledelsen at skabe den ramme for medarbejderne, der gør dem i stand til at handle på det, der giver mening for borgerne.

\section{E. Bidrager Psykiatriens Hus med ny viden om ledelse på tværs?}

\section{Kom den eksisterende viden i spil?}

Allerede i 2014 udkom den første artikel om grænsekrydsende ledelse, som jeg bidrog til. Med udgangspunkt i Ernst og Chrobot- Masons seks grænsekrydsende ledelsespraksisser undersøgte vi om disse fandtes i vores cases fra den daværende aktionsforskning (Ingerslev 2014). De seks praksisser kan beskrives således i kort form:

1) Der skal etableres en balance mellem tryghed og risikovillighed

2) Der skal skabes plads til refleksion over egne, andres og det fælles perspektiv

3) Der skal skabes et fælles grundlag i balance mellem struktur og relationer

4) Visionen skal formidles kraftfuldt til de medarbejdere, der skal realisere den

5) Borgerperspektivet kan sammenvæve de forskellige organisationers perspektiver

6) Ledelse skal bidrage til at både opgaver og identiteter transformeres

Vi genfandt alle seks praksisser i de cases, vi studerede, men fandt også, at de skulle suppleres med yderligere kompetencer, idet der var behov for at lederne:

- Udviste rummelighed og risikovillighed

- Skabte samarbejde mellem konkurrerende enheder

- Var generøse på tværs af faglige og organisatoriske grænser

Samtidig viste det sig, at lederne havde behov for at udvikle deres proceskompetencer, idet de ikke havde mulighed for at benytte de hierarkiske virkemidler i et tværgående partnerskab. I en opfølgende artikel (Ingerslev 2015) præciserede vi hvilke sociale kompetencer, der var behov for at udvikle og kom med disse anbefalinger til ledere, der skulle lede på tværs:

- Skab visionen i fællesskab

- Kommuniker visionen med borgerens behov som det højeste formål

- Skærp evnen til at sætte dig i 'de andres' sted

- Vis faglig og territorial åbenhed, risikovillighed, mod og tålmodighed

- Balancer mellem udforskning og beslutningskraft 
- Vær rollemodel

Disse anbefalinger er uddybet og suppleret i bogen På Tværs (Jørgensen 2016) og det var denne viden jeg blev inviteret til at sætte i spil i Psykiatriens Hus.

Lykkedes det at inddrage den eksisterende viden? Det gjorde det Ikke i følge en af de fuldmægtige, der var med fra start. Og jeg må give hende ret. Hun oplevede at opgaven ændrede sig. På spørgsmålet om det bidrog positivt at inddrage en forsker, siger hun: "Nej. Formålet var at få greb til at håndtere ledelses på tværs - men du blev i stedet en støtte for den daglige ledelse og synliggjorde de vanskeligheder de havde. Det blev mere personligt."

Opgaven, jeg var hyret til i Psykiatriens Hus, skiftede karakter undervejs og jeg har (endnu en gang) gjort den erfaring, at inden den forskningsbaserede viden kan komme i spil, er det nødvendigt at få ryddet op i forhistorier og eventuelle konflikter.

\section{Er der opstået ny viden om ledelse på tværs?}

Ledernes tilgang til opgaven og til ledelse var meget forskellig og de var også valgt til opgaven, fordi de var forskellige. Denne forskellighed lykkedes det ikke at udnytte konstruktivt og da jeg mødtes med lederne første gang, efter de havde været ansat i 1⁄2 år, var konfliktniveauet allerede højt. Det var faktisk så højt at jeg oplevede, at de trak sig fra hinanden og dermed den fælles ledelsesopgave. Der gik nogen tid inden jeg blev klar over problemets omfang og skiftede fokus fra at bidrage med viden til at hjælpe lederne med at håndtere de aktuelle, komplekse problemstillinger, de stod midt i. Desuden gik der over et år inden chefniveauet for alvor greb ind og sikrede hjælp bl.a. i form af en organisationskonsulent med den fornødne viden og erfaring, som lederne havde behov for at få tilført.

Det betød at arbejdet med at lave en fælles vision, strategioplæg og så videre aldrig rigtig fik fat, idet lederne i en længere periode koncentrerede sig om deres eget område og ikke udviste megen territorial åbenhed og tilgivelse, hvis deres grænser blev overtrådt.

Det høje konfliktniveau betød at forberedelsestiden ikke blev anvendt til de vigtige, forberedende, strategiske opgaver. Samtidig var huset ikke færdigt ved indflytning. Det medførte at det var oplagt nødvendigt at beskæftige sig med praktiske opgaver, der skulle løses inden huset skulle åbnes for borgerne.

Det er min vurdering at konfliktniveauet betød, at lederne foretrak at løse de mange praktiske opgaver fremfor at bruge tid på den fælles ledelsesopgave. Det var dels for opslidende for dem at 
være i konflikt, dels fik de en langt højere grad af positiv respons når de løste de praktiske udfordringer.

Derfor blev de ikke de rollemodeller som medarbejderne kunne have haft behov for. Heldigvis klarede medarbejderne sig uden. Opgaven var tydelig for alle og i de fire uger, medarbejderne havde til det forberedende arbejde fik de bygget de nødvendige relationer på tværs. Det viste sig at være hjælpsomt i det videre arbejde.

På trods af at medarbejderne var rimeligt selvkørende, registrerede de uenighederne i den daglige ledelse og oplevede, at det var den enkelte medarbejder, der selv skulle kunne samle ledelsens dobbelte perspektiv i et. I Psykiatriens Hus lykkedes det, primært fordi medarbejderne på tværs fik ejerskab til huset i løbet af forberedelsestiden.

En medarbejder foreslår, at man på en tværsektoriel institution kun har én leder, der skal kunne rumme det dobbelte perspektiv og først på chefniveau har repræsentanter fra de forskellige organisationer.

Pointen er, at hvis den daglige tværsektorielle ledelse ikke er samstemte, så kan det blive vanskeligt at være medarbejder. Gejsten hos medarbejderne har dog været så stor at manglen på samstemt ledelse ikke fik den store betydning. Der har kun været mindre ærgrelser undervejs.

Er det muligt med kun én leder for en institution med to selvbevidste ejere? Jeg tvivler på at nogen organisation vil opgive at have sit perspektiv forankret i den daglige ledelse. Det betyder at der skal arbejdes på at få etableret en samstemt ledelse, der kan balancere mellem egeninteressen og fællesinteressen.

Chefniveauet har ikke oplevet de samme udfordringer som lederne. For det første kendte de tre chefer hinanden fra tidligere samarbejder på tværs og for det andet forholdt de sig i højere grad principielt til de problemstillinger der opstod. De havde også lettere ved at gå på kompromis. Det er lettere at undgå konflikter om principielle spørgsmål end at implementere dem i dagligdagen og stå på mål for beslutningerne overfor medarbejdere og borgere. Forstået således at det er lettere at beslutte en regel om at en borger på kommunal kontrakt kan få én overnatning og en på regional kontrakt er berettiget til fem overnatninger, end det er at skulle omsætte beslutningen til en praksis, der giver mening for borgere og medarbejdere.

Når politikere og topledelsen beslutter sig for at etablere en tværsektoriel afdeling, så skal topledelsen bidrage til at det bliver muligt for chefniveauet at afsætte tid og ressourcer til en tæt opfølgning. Det er ikke sikkert at der bliver behov for chefstøtte, men det er ulykkeligt hvis ledere 
ikke får den nødvendige hjælp, fordi cheferne er optaget af mange konkurrerende projekter eller ikke har kompetence til at kaste sig ind i konflikterne.

Der er (endnu) ikke skabt ny viden på begrebsniveau om tværgående ledelse i Psykiatriens Hus. Den nødvendige viden findes allerede. Det drejer sig om at få den viden omsat til handling. Vi har eksempelvis længe vidst at forhistorien har betydning, når der skal ledes på tværs og at man som chef og leder er nødt til at kaste sig ind i de konflikter, der opstår. Tidligere erfaringer viser at konflikter løses bedst i det uformelle rum (Digmann 2014/15), der opstår når man eksempelvis går en tur sammen.

Det lykkedes ikke at omsætte denne viden til konkrete lederhandlinger i Psykiatriens Hus, måske fordi forskeren var hyret til en opgave, der viste sig at være en anden.

Som aktionsforsker er det nødvendigt at få afdækket den reelle opgave og få det gjort hurtigt. Er opgaven en anden end den først antagede, så skal kontrakten justeres. Samtidig er det nødvendigt med en tæt opfølgning for at bidrage til at besluttede handlinger bliver til virkelighed.

Først i da aktionslæring blev til aktionsforskning i sommeren 2020 blev konfliktniveauet i den daglige ledelse så tydelig, at cheferne greb ind med den konstruktive støtte, der var nødvendig, for at lette ledernes arbejde, så de kan komme i mål med at realisere visionen.

Når jeg konkluderer at der ikke er opstået ny viden på begrebsniveau, hvorfor så overhovedet bruge tid på Psykiatriens Hus?

Det skyldes, at der er en lang række konkrete erfaringer, som man kan lade sig inspirere af. Ét er viden på begrebsniveau - noget andet er hvordan denne viden omsættes til handling. Her bidrager Psykiatriens Hus med ny viden om hvordan den praktiske ledelsesudøvelse kan gennemføres, når man på tværs af fag- og sektorgrænser skal løse opgaverne for borgerne.

Desuden er det endnu engang blevet tydeligt, at der ikke er et quick fix, når man skal arbejde på tværs. Det er et langt sejt træk at komme fra ord til handling og det kræver vedholdenhed, tålmodighed og en evne til at tilgive og prøve på ny, når noget går galt.

\section{F. Afrunding}

\section{Konklusion}

Psykiatriens Hus er på vej til for alvor at designe tilbud, der tager udgangspunkt i borgerne ønsker og behov. Der er dog stadig vanskeligheder, der skal overvindes. Det stiller krav til modige ledere 
og chefer, der vil gå i brechen for borgerne og bidrage til at etablere sammenhængende tilbud og derved skabe en ny fælles kultur, der hverken er regional eller kommunal.

Medarbejderne har behov for at kunne samarbejde med borgerne uden at skulle skele til, om de er henvist fra det kommunale eller regionale system. De efterspørger mere mod og flere prøvehandlinger og drømmer om, at alle bliver endnu bedre til at bruge de andres kompetencer og frygter, at udefra kommende pres - som f.eks. omorganiseringer, besparelser eller pandemier - kan føre til et tilbagefald til 'vi plejer' kulturen.

Det har afgørende betydning, at parterne bliver ved med at være nysgerrige på hinanden og sætte ord på dét, der undrer. Lige så vigtigt er det at anerkende, at tid til forberedelse og træning i at arbejde på tværs skal prioriteres. Samtidig efterspørger borgerne, at de regionale og kommunale tilgange og tilbud kan flettes, så de til hver en tid matcher den enkelte borgers behov.

Mine data peger på, at det er en lettere eller enklere ledelsesopgave at skulle sætte rammen for det tværsektorielle samarbejde end i det daglige at skulle virkeliggøre visionen. Det siger næsten sig selv, at det er mere komplekst dagligt at skulle gøre visionen til virkelighed, end det er at formulere visionen.

Alle lederteams skal bruge tid på at tale sig ind på hinanden på tværs af fag, erfaringsgrundlag og temperamenter. Herudover har opgaven for ledelsen i Psykiatriens Hus været både at skulle varetage hjemorganisationens og husets interesser, uden at nogen oplever sig trådt for nær. Hvis ikke dette dobbelte ledelsesrum er afklaret fra start og kan justeres undervejs, som parterne bliver klogere, så bliver det unødigt vanskeligt at lede på tværs.

\section{Generelle anbefalinger}

På tværs af de tværfaglige og tværsektorielle cases, jeg har studeret, så tegner der sig en række anbefalinger, der forhåbentlig kan inspirere jer, der skal i gang:

- Prioriter tid til forberedelse og læring undervejs. De øverste ledelsesniveauer, der udarbejder rammen for samarbejdet, kan med fordel afsætte tid til egen forberedelse og sørge for, at der opsamles læring undervejs. I bør sikre, at den daglige ledelse får tilstrækkelig tid til at forberede sig ledelsesmæssigt og ikke kun skal sikre driften. Den daglige ledelse bør sikre sig, at de (også) får afsat tid til de langsigtede strategiske ledelsesopgaver, og at de får den nødvendige støtte undervejs (uden at skulle bede om den) både fra chefgruppen og af en ekstern supervisor efter behov. 
- På alle ledelsesniveauer er det vigtigt at få afklaret, hvilket ledelsesrum man har. Hvor langt kan man eksempelvis gå for at opbygge en fælles kultur, uden at blive forkastet af hjemorganisationen. Der er selvfølgelig lovgivning, der sætter grænser; men i lige så høj grad er det lokale/regionale beslutninger, der opleves som barrierer for ledernes handlerum. Hvis ikke man på forkant får forhandlet en ramme, som alle på tværs af ledelsesniveauerne er tilfredse med, så vil der ofte opstå problemer, når de usynlige forventninger udfordres.

- Når forskellige fag og organisationer mødes om en fælles opgave, og man undres over de andres perspektiv på sagen, så er det vigtigt at fastholde en nysgerrig tilgang for at prøve at blive klogere på de andre og få nedbrudt eventuelle fordomme. På forhånd aftalte spilleregler kan medvirke til, at der etableres en ny kultur.

- Det er uundgåeligt, at der opstår problemer eller ligefrem konflikter på kryds og tværs i samarbejdet. De kan både opstå mellem ledelsesniveauerne eller på tværs af fag- og sektorgrænser. Det har afgørende betydning, at enhver leder tager ansvar for udfordringerne så tidligt som muligt, også selv om man må gå ind i kollegaens ledelsesrum for at handle. Det værste, man kan gøre, er at gøre ingenting og forvente, at en konflikt går over af sig selv. Ofte har de ledere, der er involverede i en konflikt, ikke lyst til at bede om hjælp, for ikke at signalere, at de har problemer. Derfor kan det være en god idé for chefniveauet med mellemrum at tage en uformel kontakt blot for at få en fornemmelse af, om alt er i orden eller om lederen - hvad enten det er en ligestillet eller underordnet kollega - har behov for en refleksions samtale eller anden form for assistance.

- Når to tilgange eller kulturer skal fusionere, er det effektivt at tage udgangspunkt i det, der er det fælles tredje, og det kan ofte være borgerperspektivet. I stedet for at forhandle, om det er den ene eller anden kultur eller regelsæt, der skal 'vinde', kan det være hjælpsomt at tage udgangspunkt i, hvad borgerne har brug for. I stedet for at tro, at I ved, hvad der er vigtigt for borgerne, så skal I spørge. Jeg er ikke stødt på borgere, der ikke gerne vil hjælpe.

- I skrivende stund findes der ikke specielt meget forskningsbaseret viden om, hvordan man bedst muligt arbejder på tværs. Når der ikke findes en manual, man kan slå op i, må I i stedet eksperimentere jer frem til det, der er 'det rigtige' for jer. Det er nødvendigt, at I forholder jer til jeres ledelseshandlinger og reflekterer over, hvilke der bidrager positivt til at nå målene. Lige så vigtigt er det, at I videreformidler den erfaringsbaserede viden, der er opnået.

\section{Perspektivering}

Samarbejde på tværs er kommet for at blive, idet nødvendigheden for den offentlige sektor bliver mere og mere tydelig, når borgerne skal hjælpes bedst muligt. 
Det er ikke tilstrækkeligt, at fag, afdelinger og sektorer bliver bedre til at samarbejde. Borgerne skal også inddrages. Det gør ikke opgaven lettere. I Psykiatriens Hus 2.0 skal borgerne inviteres til at bidrage med ideer til den videre udvikling. Det kræver, at ledelsen og medarbejderne skal være åbne for ideer udefra og sikre, at disse modtages positivt.

Der er behov for at udvikle et nyt, fælles sprog. Løbende dialog og afmystificering er en nødvendighed, hvis der skal skabes tryghed parterne imellem. Der findes endnu ikke skalerede samskabelsesprojekter på de centrale velfærdsområder, og jeg er spændt på at se, om det er i Psykiatriens Hus, at det vil lykkes at samskabe, så det virkelig rykker, og hvor det får konsekvenser for den førte politik, organisering og økonomiske forvaltning.

Skal det lykkes at inddrage borgere og civilsamfund i udviklingen af næste generation af Psykiatriens Hus, så er 'systemerne' nødt til både at løsne behovet for styring og kontrol og at gentænke fagfagligheden. Samtidig er der behov for at frisætte og støtte de mange borgere, der gerne vil bidrage til samfundsudviklingen. Hvis også de borgere, der ikke normalt bliver hørt, skal have mulighed for at bidrage, kan der være behov for at understøtte dialogen, indtil parterne kan mødes i øjenhøjde. I folketingets åbningstale 2020 annoncerede Mette Frederiksen, at regeringen ville frisætte syv kommuner, så de på udvalgte velfærdsområder vil blive fritaget for så meget regulering som muligt. Det er et utroligt spændende forsøg. Dels fordi det bliver muligt at handle sig til ny viden om, hvordan den bedste skole, det bedste ældreområde skal se ud, når vi har mulighed for at begynde forfra.

Jeg glæder mig til at følge, hvordan borgerne vil blive inddraget, om kontrolbehovet kan holdes i ave, så frisættelsen bliver reel, og om beslutningstagerne stadig har is i maven, når de første fejl viser sig.

Samtidig venter jeg spændt på, hvornår frisættelsen kommer til at gælde det tværsektorielle samarbejde, for også her er der behov for en ny start, hvis sektoransvarligheden skal erstattes af borgeransvarlighed. 


\section{Referencer}

Ernst, C., Chrobot-Mason, D (2011) Boundary spanning leadership. Six practices for solving problems, driving innovation and transformation organizations. McGraw-Hill. https://doi.org/10.5465/amle.2012.0072

Dahler-Larsen, P. (2010) At fremstille kvalitative data. Syddansk Universitetsforlag.

Dall, M. O. (2016): Lethedens principper i velfærdsinnovation. Økonomistyring\&informatik. Nr 4 Vol 31. Jurist- og Økonomiforbundets Forlag.

Digmann, A, (2014/15): At lede på tværs af sektorer: nødvendigt og udfordrende! Økonomistyring\&informatik. Nr 3 Vol 30. Jurist- og Økonomiforbundets Forlag.

Digmann, A. (2019): Innovation finder sted, når grænser krydses. Erhvervspsykologi. Nr 1 Vol 17. Dansk Psykologisk Forlag.

Helm-Pedersen, L.L. (2020): Organisatorisk brugerinddragelse på en socialpsykiatrisk døgninstitution. Ph.d.-afhandling. DPU, Aarhus Universitet. https://doi.org/10.7146/aul.383

Ingerslev, K., Andersen, P.B.N., Digmann, A. (2014): Grænsekrydsende lederskab. Erhvervspsykologi. Nr. 2 Vol 12

Ingerslev, K., Andersen, P.B.N., Digmann, A. (2015): Grænsekrydsende lederskab i praksis. Erhvervspsykologi. Nr. 4 Vol 13

Jørgensen, J.H., Digmann, A., Ingerslev, K. (2016): På Tværs. Grænsekrydsende ledelse og samarbejde. Gyldendal Public.

Nielsen, A.M., Ejlersen, L.S., Digmann, A (2018): Når borgere skaber inkluderende fællesskab. Sager der Samler. Findes på www.sagerdersamler.dk

Seemann, J., Gustafsson, J. (2018): Grænsekrydsende ledelse. Ledelse på tværs af professioner og organisatoriske enheder. Working Paper, Aalborg Universitet.

Væksthus for Ledelse (2020): Chefer lyt til borgerne: Skab resultater gennem god tværsektoriel ledelse. 